\title{
STRATEGI PENERAPAN KONSEP PARIWISATA BERKELANJUTAN DALAM UPAYA PELESTARIAN KAWASAN WISATA CANDI BOROBUDUR
}

\author{
Rahmat Priyanto ${ }^{1}$ \\ STP Ars Internasional Bandung \\ Rahmat.rmp@bsi.ac.id \\ Yuliana Pinaringsih Kristiutami ${ }^{2}$ \\ AKPAR BSI Bandung \\ Yuliana.ylp@bsi.ac.id \\ Swastono Putro Pirastyo ${ }^{3}$ \\ Akademi Pariwisata Nasional Indonesia Bandung \\ Swastono.putro@gmail.com
}

\begin{abstract}
ABSTRAK
Pariwisata berkelanjutan merupakan konsep pengelolaan wisata yang berlandaskan pada pelestarian, yaitu mengelola potensi wisata dengan memperhatikan aspek keberlanjutan untuk masa depan. Tujuan penelitian ini adalah untuk merumuskan konsep pengelolaan pariwisata berbasis keberlanjutan sebagai upaya untuk melestarikan kawasan wisata candi Borobudur. Metode yang digunakan dalam penelitian ini adalah deskriptif dengan pendekatan kualitatif untuk kemudian dianalisis melalui metode EFAS, IFAS, Matriks Eksternal-Internal dan SWOT. Pengambilan data dilakukan melalui kegiatan observasi secara langsung di lapangan, serta melalui kegiatan wawancara dan studi kepustakaan. Hasil penelitian ini merumuskan empat set alternatif strategi sebagai upaya untuk mendorong pengelolaan aktifitas pariwisata yang berlandaskan pada konsep keberlanjutan.
\end{abstract}

Kata kunci: Pariwisata Berkelanjutan. Pelestarian Kawasan Wisata

\section{STRATEGY OF IMPLEMENTING TOURISM SUITAINABLE CONCEPT FOR CONSERVATION BOROBUDUR TEMPLE}

\begin{abstract}
Sustainable tourism is a tourism management concept based on conservation who concern to manage the tourism potential aspect and pay attention to future sustainability. The purpose of this study is to formulate the sustainable tourism management concept as an effort to conserve Borobudur Temple destination. This researches use qualitative descriptive method and EFAS, IFAS, External-Internal Matrix and SWOT as data analysis method. Direct observation, interview and literature study is also use to collect the data. The result of this research is four set of an alternate strategic formula to push the tourism activity management to sustainability concept management
\end{abstract}

Keywords: Sustainable Tourism, Destination Conservation 


\section{PENDAHULUAN}

Industri pariwisata saat ini menjadi salah satu industri yang memiliki perkembangan sangat signifikan dibanding industri-industri lainya. Perkembangan industri pariwisata menjadi peluang besar bagi terciptanya pembukaan lapangan kerja baru, perangsangan pembangunan dan pengentasan kemiskinan yang dapat berdampak pada perbaikan ekonomi suatu negara, namun disamping dampakdampak positif yang dihasilkan oleh industri pariwisata, muncul pula kekhawatirankekhawatiran akan dampak negatif yang dapat ditimbulkan, seperti: kerusakan alam, lingkungan, budaya, sosial, akibat dari pengelolaan pariwisata secara konvensional, yaitu pengelolaan yang hanya berorientasi pada profit saja, tanpa memperhatikan aspek-aspek pelestarianya. Pariwisata konvensional (Unsustainable Tourism) dapat meningkatkan limbah padat, degradasinya warisan dan situs budaya, penurunan keanekaragaman hayati, kerusakan satwa liar dan menyebabkan polusi yang mengarah ke sungai, danau dan laut (APEC dalam Nabiha, 2008:301). Alam dan lingkungan menjadi sumber utama dari sebagian besar destinasi pariwisata yang ada, maka konsep pariwisata berkelanjutan lahir sebagai upaya untuk meminimalkan dampak kerusakan dan kerugian yang ditimbulkan industri pariwisata. Konsep pariwisata berkelanjutan didasarkan pada prinsip-prinsip yang memiliki kesamaan dengan konsep pembangunan berkelanjutan, dimana konsep ini adalah sebuah sudut pandang baru dari pembangunan ekonomi yang berkelanjutan atau ramah lingkungan.

Pengadopsian konsep pembangunan berkelanjutan untuk diterapkan pada industri pariwisata muncul pada tahun 90an, dimana pariwista berkelanjutan adalah sebuah konsep yang berbanding terbalik dengan konsep pariwisata konvensional (konsep pariwisata yang hanya berorientasi pada profit saja), konsep pariwisata berkelanjutan adalah konsep yang berorientasi pada profit tetapi dengan tetap memperhatikan aspek-aspek keberlangsungan dari sumber utama destinasi wisata dan lingkunganya, sehingga keberadaan konsep pariwisata berkelanjutan saat ini menjadi isu utama bagi pengembangan suatu kawasan wisata di berbagai negara.

Cronin (Sharpley, 2000:1), mengkonsepkan pariwisata berkelanjutan sebagai pembangunan yang didasarkan pada dua hal, keberlanjutan pariwisata sebagai aktifitas ekonomi dan membentuk pariwisata sebagai elemen kebijakan pembangunan berkelanjutan yang jauh lebih luas. Pembangunan dan pengembangan pariwisata berkelanjutan harus sesuai dengan prinsip-prinsip pembangunan berkelanjutan (Stabler et all dalam Sharpley, 2000:1).

Prinsip dasar dalam membangun pariwisata berkelanjutan sangat terkait dengan prinsip pembangunan berkelanjutan, dimana pendekatan holistik sangat penting untuk diterapkan secara umum, baik pada sistem pariwisata ataupun pada individu di daerah tujuan wisata. Meskipun pariwisata diterima dan terintegrasi dalam strategi pembangunan nasional dan lokal, namun fokus utama pembangunan pariwisata berkelanjutan masih ke arah terpusat pada produk. Oleh karenanya pada tingkat operasional sulit mengatur penerimaan yg komplek, fragmentasi, pembagian multisektor dari keuntungan pariwisata secara alamiah (Sharpley, 2000:9 -11).

Lebih jauh pengembangan pariwisata berkelanjutan di lapangan harus dapat mempertemukan kebutuhan-kebutuhan wisatawan dengan keperluan-keperluan 
masyarakat lokal, sekaligus melindungi dan meningkatkan kesempatan untuk masa depan. Hal ini menjadi pertimbangan utama untuk pengelolaan semua sumber daya yang sedemikian rupa, sehingga kebutuhan ekonomi, sosial, dan estetika dapat terpenuhi dengan tetap menjaga integritas budaya, kepentingan proses ekologi, keanekaragaman hayati, dan sistem pendukung kehidupan (WTO dalam Conaghan, 2010:2).

Selain daripada itu, pengelolaan suatu kepariwisataan harus sesuai dengan prinsip-prinsip pariwisata berkelanjutan yang didasarkan pada empat pilar, (Mckercher, 2003:4) mengidentifikasikan prinsip-prinsip pariwisata berkelanjutan yang didasarkan pada empat pilar, yaitu:

\section{Keberlanjutan Ekonomi}

a. Bentuk kemitraan seluruh rantai yang meliputi bisnis lokal mikro sampai organisasi multinasional

b. Mengunakan pedoman pelatihan dan sertifikasi yang telah disetujui secara internasional

c. Mempromosikan mengenai etis dan perilaku sadar lingkungan kepada klien

d. Membuat variasi produk melaui pengembangan dari berbagai kegiatan wisata.

e. Berkontribusi melalui pendapatan yang dihasilkan untuk membantu pelatihan, etika pemasaran dan pengembangan produk

f. Menyediakan insentif keuangan kepada perusahaan untuk mengadopsi prinsip-prinsip keberlanjutan

\section{Keberlanjutan Ekologi}

a. Aturan-aturan pelaksanaan harus ditetapkan di semua tingkatan pariwisata

b. Pedoman untuk operasional pariwisata, penilaian dampak dan pemantauan dampak kumulatif harus di bentuk

c. Merumuskan strategi kebijakan pengembangan pariwisata nasional, regional dan lokal secara konsisten dengan tujuan pembangunan berkelanjutan secara keseluruhan

d. Institusi dasar studi analisis mengenai dampak lingkungan

e. Memastikan bahwa desain, perencanaan, pembangunan dan pengoperasian fasilitas sesuai dengan prinsip-prinsip keberlanjutan Memastikan pariwisata di kawasan lindung seperti Taman Nasional, bergabung dan patuh pada perencanaan manajemen yang baik

f. Memantau dan melakukan penelitian tentang dampak yang sebenarnya dari pariwisata

g. Mengidentifikasi perilaku yang dapat diterima di kalangan wisatawan

h. Mempromosikan perilaku kepariwisataan yang bertanggung jawab

\section{Keberlanjutan Budaya}

a. Kepariwisataan harus diprakarsai berdasarkan pendapat masyarakat luas.

b. Harus ditetapkan program pendidikan dan pelatihan guna peningkatan, pengelolaan kebudayaan dan sumber daya alam. 
c. Melestarikan keragaman budaya

d. Menghormati tanah dan hak milik penduduk lokal

e. Jaminan perlindungan alam, keaslian budaya lokal dan khususnya pengetahuan tradisional

f. Bekerja secara aktif dengan para pemimpin adat dan kelompok minoritas untuk memastikan bahwa adat kebudayaan masyarakat digambarkan secara akurat dan bertanggung jawab.

g. Memperkuat, memelihara dan mendorong kemampuan masyarakat untuk memelihara dan menggunakan ketrampilan tradisional.

h. Mendidik wisatawan tentang perilaku yang diinginkan dan dapat diterima

i. Mendidik industri pariwisata tentang perilaku yang diinginkan dan dapat diterima

\section{Keberlanjutan Lokal}

a. Masyarakat harus mempertahankan kontrol atas pengembangan kepariwisatan

b. Industri pariwisata harus menyediakan lapangan kerja berkualitas bagi warga masyarakat

c. Mendorong usaha untuk meminimalkan efek negatif kepada masyarakat lokal dan berkontribusi positif kepada mereka

d. Pastikan pemerataan keuntungan finansial di seluruh mata rantai

e. Memberikan insentif keuangan bagi bisnis lokal untuk memasuki indsutri pariwisata

f. Meningkatkan kapasitas sumber daya manusia lokal

Candi Borobudur sebagai salah satu destinasi wisata unggulan yang ada di Indonesia, selain sebagai suatu destinasi wisata, keberadaan candi Borobudur juga merupakan suatu alat pelestarian sejarah agama Budha di pulau Jawa, sehingga aspek kelestarianya harus tetap terjaga agar dapat menjadi bukti sejarah yang dapat diwariskan pada generasi mendatang. Namun pada kenyataanya kondisi yang terjadi saat ini, kelestarian candi Borobudur terancam dengan adanya permasalahan-permasalahan yang ditimbulkan oleh alam maupun aktifitas kepariwisataan.

Permasalahan yang ditimbulkan oleh aktifitas kepariwisataan berperan besar dalam merusak pelestarian candi Borobudur sebagai situs warisan sejarah, beberapa diantaranya adalah polusi yang ditimbulkan oleh banyak aktifitas kendaraan wisatawan di sekitar candi Borobudur, kegiatan vandalisme yang dilakukan oleh wisatawan seperti corat coret maupun menaiki patung-patung yang berada di dalam candi Borobudur, lebih jauh lagi adalah ancaman terhadap kelestarian batuan candi Borobudur yang disebabkan oleh banyaknya jumlah wisatawan yang berada di atas candi Borobudur.

Keberadaan aktifitas kepariwisataan di candi Borobudur disisi lain berdampak positif pada peningkatan kesejahteraan ekonomi masayarakat sekitar, peningkatan pendapatan pemerintah daerah maupun peningkatan devisa negara melalui kunjungan wisatawan mancanegara. Oleh karena itu dibutuhkan strategi pengelolaan pariwisata yang mampu mendorong berkambangnya aktifitas kepariwisataan yang berlandaskan pada nilai-nilai pelestarian candi Borobudur 
sebagai situs peninggalan bersejarah. Fungsi pelestarian bila ditinjau dari segi bentuk peninggalan purbakala atau arkeologi adalah tidak berbeda jauh dari fungsi peninggalan purbakala lain pada umumnya yaitu,

1. Sebagai bukti dan sumber sejarah peninggalan bangsa di masa lalu yang sangat penting, baik bagi generasi sekarang maupun bagi generasi yang akan datang.

2. Sebagai sarana pendidikan seumur hidup, terutama bagi generasi muda yang akan memimpin bangsa di kemudian hari.

3. Sebagai sarana pendidikan nasional.

4. Sebagai Land Mark.

5. Fungsi tambahan lainnya yang diberikan, adalah sebagai menu jiwa (Ardana, 1983: 14)

Dipertegas dengan Undang-Undang Republik Indonesia No.11 Tahun 2010

mengenai pelestarian atau konservasi yang memberikan gambaran mengenai Lingkup Pelestarian Cagar Budaya yang meliputi,

1. Perlindungan

Perlindungan yaitu upaya mencegah dan menanggulangi dari kerusakan, kehancuran, atau kemusnahan. Perlindungan merupakan unsur terpenting dalam sistem pelestarian cagar budaya, unsur ini mempengaruhi unsur-unsur lain yang pada akhirnya diharapkan menghasilkan umpan balik pada upaya perlindungan.

2. Pengembangan

Pengembangan yaitu peningkatan potensi nilai, informasi, dan promosi Cagar Budaya serta pemanfaatannya melalui Penelitian, Revitalisasi, dan Adaptasi secara berkelanjutan serta tidak bertentangan dengan tujuan Pelestarian. Sebaliknya unsur pengembangan lebih banyak berhubungan dengan potensipotensi yang menyatu dengan benda, bangunan, struktur atau situs yang dipertahankan. Kegiatannya bukan dalam bentuk konservasi, restorasi, atau pemeliharaan objek misalnya, melainkan upaya pengembangan informasi, penyusunan bahan edukasi atau sebagai obyek wisata.

3. Pemanfaatan

Pemanfaatan adalah pendayagunaan Cagar Budaya untuk kepentingan sebesar-besarnya kesejahteraan rakyat dengan tetap mempertahankan kelestariannya. Kegiatan pada unsur pemanfaatan yang juga menyentuh fisik dari cagar budaya seperti halnya perlindungan, bedanya ialah pada unsur ini kegiatannya terbatas pada upaya revitalisasi atau adaptasi untuk menyesuaikan kebutuhan baru dengan tetap mempertahan keaslian obyek. (Widayawati et all, 2013:306)

\section{METODOLOGI}

Metode penelitian yang digunakan dalam penelitian ini adalah metode penelitian deskriptif. Dengan pendekatan yang digunakan secara kualitatif. Metode pendekatan kualitatif lebih menekankan analisisnya pada proses penyimpulan deduktif dan induktif serta pada analisis dinamika hubungan antar fenomena yang diamati, dengan menggunakan logika ilmiah (Harun, 2007:5). Penelitian ini dikelompokkan pada dua sumber data yaitu, data primer dan data sekunder. Data primer adalah sumber data yang diperoleh secara langsung di area wisata candi 
Borobudur, adapun data yang diperoleh dapat berupa lisan dan tulisan, data-data tersebut diperoleh melalui kegiatan observasi lapangan dan wawancara dengan pihak dari Taman Wisata Candi Borobudur dan Balai Konservasi Borobudur sebagai pengelola di area wisata candi Borobudur. Data sekunder adalah data yang diperoleh dari literatur, dokumen, hasil penelitian, modul, buku, majalah, website dan sumber-sumber tidak langsung lainya yang mempunyai keterkaitan dengan permasalahan yang sedang diteliti, adapun bentuknya dapat berupa profil perusahaan, arsip, peta dan lain sebagainya. Metode pengumpulan data penelitian dilakukan melalui penggunaan metode observasi, wawancara atau interview mendalam (in-depth interview) dan metode dokumentasi.

Data-data yang Analisis data penelitian dilakukan melalui penggunaan 2 metode analisis, metode analisis yang pertama menggunakan metode Matrik Eksternal-Internal, Matrik Ekstrnal-Internal digunakan untuk menentukan langkah strategi yang harus dilakukan oleh suatu perusahaan, data analisis matrik ini menggunakan nilai total hasil pejumlahan kolom bobot $\mathrm{x}$ rating pada analisis EFAS dan IFAS, nilai tersebut dipakai untuk menentukan posisi perusahaan dan bentuk strategi apa yang harus dilakukan. Metode analisis yang digunakan selanjutnya adalah metode analisis SWOT, analisis SWOT adalah metode analisis yang mengidentifikasikan berbagai faktor secara sistematis untuk merumuskan strategi perusahaan. Analisis ini didasarkan pada logika yang dapat memaksimalkan kekuatan (Strength) dan peluang (Opportunities), namun secara bersamaan dapat meminimalkan kelemahan (Weakness) dan ancaman (Threats). (Rangkuti, 2006:18).

\section{HASIL DAN PEMBAHASAN}

\section{Analisis Deskriptif Program Yang Berkaitan Dengan Konsep Pariwisata Berkelanjutan di Candi Borobudur.}

Penerapan konsep pariwisata berkelanjutan di kawasan wisata candi Borobudur secara umum dan area wisata candi Borobudur secara khusus sudah diupayakan oleh pengelola candi Borobudur. Hal itu terlihat pada program-program dan arah kebijakan yang diberlakukan, meskipun masih diperlukanya penambahan, pengawasan dan penyesuaian agar konsep pariwisata berkelanjutan dapat diterapkan secara maksimal dan sejalan dengan kepentingan Stakeholder terkait seperti: wisatawan, masyarakat, pengelola dan pemerintah. Analisis deskripsi program pariwisata berkelanjutan di Candi Borobudur terbagi pada empat kategori sebagai berikut: keberlanjutan ekonomi, lingkungan, budaya dan masyarakat local.

\section{Keberlanjutan Ekonomi}

\section{a. Kerjasama}

Pihak-pihak yang saat ini menjalin kerjasama dengan Taman wisata Candi Borobudur terbagi ke dalam dua klasifikasi, pihak pertama yaitu Corporate (perusahaan, instansi pemerintah dan organisasi) dan bentuk kerjasama yang terjalin dengan pihak kedua yaitu dengan masyarakat sekitar. Adapun bentuk kerja sama yang terjalin dengan Corporate dituangkan ke dalam MOU, untuk kemudian dibuat kesepakatan-kesepakatan yang dapat menguntungkan kedua belah pihak. Beberapa perusahaan yang telah menjalin kerjasama dengan pengelola wisata Candi Borobudur diantaranya PT Coca Cola, PDAM Kb Magelang dan Kluster 
Borobudur. Sedangkan bentuk kerja sama yang terjalin dengan masyarakat sekitar lebih bersifat kepada pemberdayaan, sehingga profit bukan menjadi tujuan utama dari kerja sama yang terjalin

\section{b. Promosi}

Kegiatan promosi area wisata candi Borobudur yang dilakukan oleh pihak Taman wisata Candi Borobudur terbagi ke dalam dua lingkup promosi, yaitu nasional dan internasional. Kegiatan promosi di lingkup nasional, Taman Wisata Candi Borobudur melakukan berbagai macam kegiatan seperti Roadshow dan Java

\section{c. Promo}

Kegiatan promo dilakukan ke daerah-daerah di Indonesia dengan menyediakan brosur dan menjalin kerjasama dengan Dinas Pariwisata terkait untuk bersamasama mempromosikan area wisata Candi Borobudur. Sedangkan untuk kegiatan promosi di lingkup internasional adalah dengan mengikuti even-even internasional kepariwisataan dan budaya, salah satunya Event Travelmart di Malaysia.

\section{Keberlanjutan Ekologi (Amdal)}

Penelitian dan pengkajian terhadap AMDAL (Analisis Dampak Lingkungan) di area wisata candi Borobudur dan kawasan sekitarnya begitu sangat diperhatikan, mengingat bangunan candi Borobudur yang telah berumur ribuan tahun sangat rapuh terhadap perubahan-perubahan alam, seperti iklim, bencana alam, gempa bumi. Selain itu dilakukan AMDAL terhadap dampak dari adanya aktifitas kepariwisataan yang berlangsung di Candi Borobudur dan sekitarnya.

Kegiatan dengan AMDAL di area wisata Candi Borobudur dan kawasan sekitarnya dilakukan oleh dua instansi pengelola candi Borobudur, yaitu Taman Wisata Candi Borobudur dan Balai Konservasi Borobudur. Hasil analisis dampak lingkungan Taman Wisata Candi Borobudur dirumuskan ke dalam buku Dokumen Pengelolaan Lingkungan, sedangkan hasil analisis dampak lingkungan dari Balai Konservasi Borobudur dirumuskan pada Laporan Kerja Akhir Tahunan. Proporsi penelitian dampak lingkungan yang dilakukan oleh Taman Wisata Candi Borobudur berfokus pada bagaimana pengaruh dampak kegiatan operasional pariwisata di area candi Borobudur terhadap lingkungan sekitarnya, sedangkan Balai Konservasi Borobudur berfokus kepada bagaimana pengaruh iklim dan lingkungan terhadap candi Borobudur dan juga sebaliknya.

\section{Keberlanjutan Budaya}

Program dan kebijakan Taman Wisata candi Borobudur yang terkait dengan keberlanjutan budaya dirumuskan pada beberapa poin sebagai berikut:

a. Program Pelatihan (Meningkatkan Potensi Budaya)

Dalam upaya untuk mendukung aspek keberlanjutan budaya masyarakat sekitar, Taman Wisata Candi Borobudur memiliki program pelatihan dan pembinaan kebudayaan, salah satunya pembinaan seni tari, yang mana kegiatan ini ditujukan bagi anak-anak sekolah SD, SMP dan setingkat SMU di daerah sekitar area wisata candi Borobudur, program pelatihan dan pembinaan ini selain untuk mendukung aspek keberlanjutan budaya lokal, diharapkan juga dapat meningkatkan daya tarik bagi wisatawan yang secara tidak langsung berdampak positif pada peningkatan aspek kepariwisatan di sekitar area wisata candi Borobudur. 
b. Kerja Sama (Melestarikan Kebudayaan Masyarakat Sekitar)

Taman Wisata Candi Borobudur menjalin kerja sama dengan masyarakat sekitar dalam upaya utuk melestarikan budaya, salah satunya dengan ASKRAB (Asosiasi Kesenian rakyat Borobudur), jalinan kerja sama itu dituangkan ke dalam MOU, dimana Taman Wisata candi Borobudur memiliki tugas untuk memberikan pelatihan dan pembinaan seni tari, untuk kemudian memberi kesempatan pementasan di dalam area wisata candi Borobudur pada hari minggu atau pada saat adanya kunjungan tamu penting seperti tamu Negara.

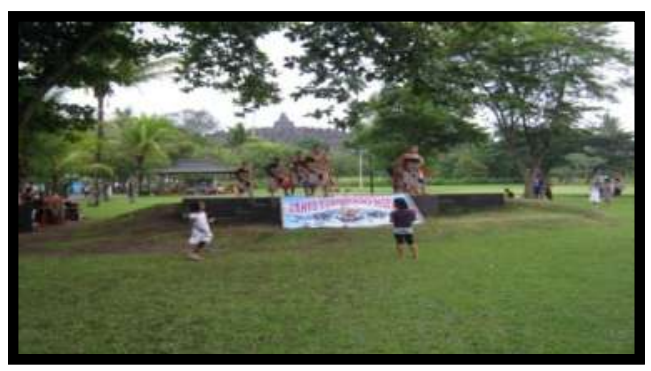

Gambar 1

Pementasan Kesenian Tari

\section{c. Pameran}

Salah satu upaya untuk melestarikan kebudayaan daerah, Taman Wisata Candi Borobudur mengadakan pameran kebudayaan BIF (Borobudur International Festival), pameran ini diadakan 2 tahun sekali dalam rangka untuk memperkenalkan kebudayaan-kebudayaan sekitar dan umumnya kebudayaan indonesia kepada dunia internasional, pameran ini diikuti negara-negara lain, untuk kemudian mementaskan juga kesenian-kesenian yang dimiliki masing-masing negara kepada pengunjung pameran.

\section{d. Program Sarung Batik}

Program pemakaian sarung batik kepada pengunjung yang akan menaiki bangunan candi Borobudur mulai diberlakukan pada 15 Maret 2011, dimana tujuan dari diberlakukanya program ini sebagai upaya untuk mengenalkan batik sebagai identitas kebudayaan asli Indonesia.

\section{Keberlanjutan Masyarakat Lokal}

Program dan kebijakan terkait keberlanjutan masyarakat local dirumuskan pada beberapa poin sebagai berikut:

\section{A. Program Pemberdayaan Masyarakat}

a. DMO (Destination Managemen Organizer)

Destination Managemen Oraganizer adalah sebuah program kerjasama antara Taman Wisata Candi Borobudur dengan desa-desa yang mendapat pembinaan dari pemerintah. Tujuan dari program ini untuk menggali potensi-potensi pariwisata apa saja yang ada di desa-desa sekitar area wisata candi Borobudur sehingga desa-desa tersebut dapat dikembangkan untuk dapat menjadi tujuan alternatif wisatawan setelah mengunjungi candi Borobudur.

b. Pelatihan 
Kegiatan pelatihan dilakukan oleh Taman Wisata Candi Borobudur bekerjasama dengan pihak-pihak lain untuk meningkatkan kapasitas Sumber Daya Manusia masyarakat sekitar, sehingga masyarakat diharapkan dapat memaksimalkan potensi pariwisata yang ada di sekitar kawasan wisata candi Borobudur. Adapun bentukbentuk pelatihan yang diberikan adalah sebagai berikut : pelatihan bahasa asing bagi kusir delman Tilik Ndeso, Tilik Ndeso adalah paket wisata delman yang membawa wisatawan keliling ke desa-desa sekitar candi Borobudur, pelatihan Merchandising, Packaging dan tata kelola keuangan bagi pedagang di sekitar area wisata candi Borobudur.

\section{B. Penyediaan Lapangan Kerja}

Keberadaan Taman Wisata Candi Borobudur sebagai pengelola area wisata candi Borobudur berdampak positif pada penyerapan tenaga kerja masyarakt sekitar, dimana mayoritas pegawai Taman Wisata Candi Borobudur berasal dari masyarakat sekitar candi Borobudur. Sistem perekrutan pegawai di dasarkan pada minimal strata pendidikan ataupun non strata pendidikan yang lebih bersifat pada pemberdayaan

\section{Insentif Keuangan}

Taman Wisata Candi Borobudur memiliki program-program pemberian insentif keuangan seperti PKBL (Program kemitraan bina lingkungan) yang bertujuan untuk memberikan pinjaman lunak bagi UKM (usaha kecil menegah ) masyarakat sekitar dan program pemberian bantuan bagi pembangunan fasilitas-fasilitas umum di sekitar area wisata candi Borobudur, seperti bantuan bagi pembangunan atau perbaikan mushola, jalan dan fasilitas-fasilitas umum lainya

\section{Analisis Deskriptif Faktor Penghambat Konsep Pariwisata Berkelanjutan Di Kawasan Wisata Candi Borobudur}

1. Kesadaran Pengunjung Akan Pelestarian Masih Kurang

Masih lemahnya kesadaran pengunjung akan kelestarian candi Borobudur menjadi salah satu faktor penghambat konsep pariwisata berkelanjutan di area wisata candi Borobudur. Upaya-upaya pelestarian terus dilakukan oleh pengelola, namun bentuk vandalisme seperti buang sampah sembarangan, corat-coret, menyelipkan sampah pada nat-nat bangunan candi masih ditemukan, sehingga bentuk-bentuk vandalisme tersebut menggambarkan masih kurangya kesadaran pengunjung akan pelestarian, hal itu didasarkan pada data salah satu vandalisme corat-coret pada bangunan candi Borobudur sebagai berikut :

Tabel 1

Jumlah Vandalisme (Corat-Coret) Di Bangunan Candi Borobudur

\begin{tabular}{cc}
\hline Tahun & Jumlah \\
\hline 2008 & 10 \\
2009 & 7 \\
2010 & 7 \\
2011 & 3 \\
2012 & 8 \\
\hline
\end{tabular}

Sumber: Balai Konservasi Borobudur 


\section{Belum Sinergi Diantara Stakeholder Terkait}

Salah satu faktor pengahambat konsep pariwisata berkelanjutan dan pelestarian di area dan kawasan wisata candi Borobudur adalah belum sinerginya Stakeholder terkait, sehingga hal itu berdampak pada belum berjalan secara maksimalnya tingkat koordinasi, komunikasi dan kerjasama di antara Stakeholder. Faktor tersebut didasarkan pada data hasil wawancara yang telah peneliti lakukan dengan narasumber Bapak Irwan Suryanta sebagai berikut:

"Sinergi hanya mudah diucapkan, dikatakan, disampaikan, dibicarakan tidak pernah dilaksanakan, hambatan yang paling dominan adalah itu, jadi belum bisa sinergi, belum bisa paham bahwa pariwisata ini harus dikelola secara sinergi, karna pariwisata tidak bisa berdiri sendiri”.

\section{Akomodasi Pementasaan Seni Tari}

Panggung dan kesempatan pementasan seni tari yang ada saat ini belum dapat mengakomodir pementasan siswa tari binaan secara menyeluruh, dikarenakan jumlah siswa tari binaan yang banyak tetapi kesempatan untuk mengekpresikanya kepada khalayak umum masih terbatas, beberapa kesempatan itu diantaranya hari minggu pementasan di dalam area wisata candi Borobudur, ketika ada tamu penting/ negara dan ketika disisipkan pada pagelaran Sendratari Ramayana Yogyakarta, sedikitnya kesempatan pementasan akan berdampak pada kurang maksimalnya pemanfaatan kebudayaan asli masyarakat lokal dan kondisi seni tari yang ada belum dapat menjadi komoditi unggulan pariwisata seperti halnya di Bali. Hal itu didasarkan pada data hasil wawancara yang peneliti lakukan dengan narasumber Bapak. Mahmudi sebagai berikut:
Anak-anak untuk tari mereka belum tau akan kemana, karna untuk pertunjukan disini agak kurang, jadi tidak semua anak-anak yang belajar tari itu bisa ditampilkan, untuk saat ini antisipasinya kita sisipkan anak-anak ini ke pertunjukan Sendra Tari Ramayana di Jogjakarta.

\section{Lapangan Kerja Di Luar Lingkup Pariwisata Masih Minim}

Ketergantungan ekonomi masayarakat sekitar terhadap keberadaan destinasi wisata candi Borobudur sangat besar, hal itu dikarenakan lapangan kerja di luar lingkup kepariwisataan masih minim, sehingga menjadi pedagang atau penawar jasa di area wisata candi Borobudur menjadi pilihan yang paling mungkin untuk dilakukan. Hal tersebut berdampak pada area wisata yang terlihat kurang tertib dikarenakan banyaknya jumlah pedagang atau penawar jasa di dalam atau di sekitar area wisata candi Borobudur.

\section{Analisis Strategi Pariwisata Berkelanjutan}

Hasil penelitian yang disajikan berupa data-data hasil analisis melalui metode EFAS, IFAS dan analisis SWOT

\section{Analisis Faktor Eksternal}

Analisis faktor eksternal kawasan wisata candi Borobudur dilakukan untuk mengidentifikasi aspek peluang dan ancaman dari eksternal apa saja yang dapat mempengaruhi kelestarian kawasan wisata candi Borobudur, baik yang datang dari factor wisatawan, masyarakat maupun dari pemerintah daerah setempat ataupun 
pemerintah pusat. Berikut ini penyajian data nilai bobot peluang dan ancaman yang diperoleh setelah dilakukan analisis melalui metode EFAS sebagai berikut:

Tabel 2

Hasil Analisis Eksternal Faktor Analisis Strenght

\begin{tabular}{|c|c|c|c|c|}
\hline $\begin{array}{c}\text { Faktor-Faktor } \\
\text { Strategi Eksternal }\end{array}$ & Bobot & Rating & Skor & Komentar \\
\hline $\begin{array}{l}\text { Peluang } \\
\text { - } \quad \text { Agenda wisata sekolah } \\
\text { Brand image atau persepsi } \\
\text { pengunjung terhadap candi } \\
\text { Borobudur tinggi } \\
\text { - } \quad \text { Perhatian pemerintah } \\
\text { - } \quad \text { Perhatian dunia internasional } \\
\text { - } \quad \text { Adanjungan tokoh penting/ negara } \\
\text { masyarakat sekitar masih kental } \\
\quad \text { Ancaman } \\
\text { - } \quad \text { Perilaku pengunjung } \\
\text { Bencana alam } \\
\text { Kesadaran pengunjung akan } \\
\text { pelestarian masih kurang } \\
\text { Keberlangsungan aspek ckonomi } \\
\text { sangat tergantung pada } \\
\text { keberadaan candi Borobudur } \\
\text { Perubahan iklim } \\
\text { Beban berat pengunjung di atas } \\
\text { bangunan candi }\end{array}$ & $\begin{array}{l}0,08 \\
0,07 \\
0,07 \\
0,08 \\
0,10 \\
0,09 \\
0,08\end{array}$ & $\begin{array}{l}3 \\
3 \\
3 \\
3 \\
1 \\
1 \\
2\end{array}$ & $\begin{array}{l}0,24 \\
0,21 \\
0,21 \\
\\
0,24 \\
\\
0,10 \\
0,09 \\
0,16\end{array}$ & 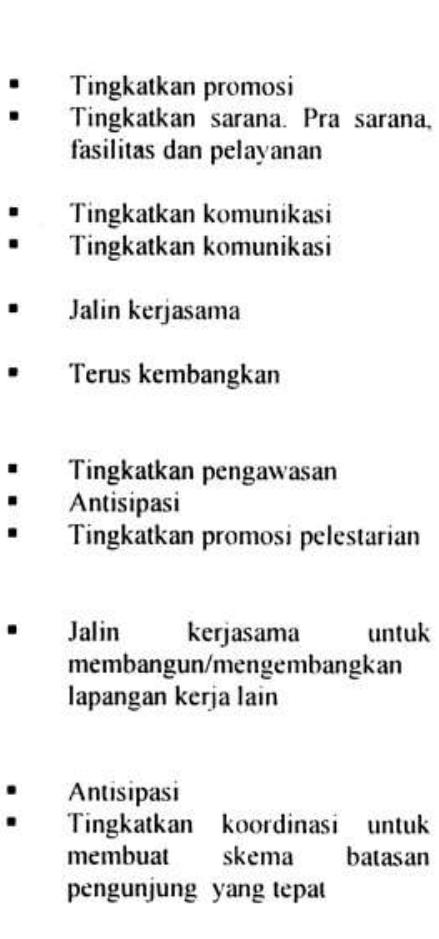 \\
\hline
\end{tabular}

Berdasarkan hasil analisis data factor eksternal pada tabel 2 terdapat masing-masing 6 peluang dan ancaman eksternal yang dapat berdampak ataupun dimanfaatkan bagi keberlangsungan destinasi wisata candi Borobudur. Keseluruhan point-point skor ancaman dan peluang yang ada, maka apabila dijumlahkan keseluruhan skornya akan berjumlah 2,17, dimana skor tersebut menunjukan bahwa hasil analisis terhadap factor eksternal destinasi wisata candi Borobudur memiliki penilaian yang Cukup Baik.

\section{Analisis Faktor Internal}

Analisis factor internal dilakukan untuk mengetahui factor-faktor internal apa saja yang dapat mempengaruhi keberlangsungan destinasi wisata candi Borobudur, berikut ini penyajian data hasil analisis terhadap factor internal candi Borobudur: 
Tabel 3

Hasil Analisis Internal Faktor Analisis Strenght

\begin{tabular}{|c|c|c|c|c|}
\hline $\begin{array}{l}\text { Faktor-Faktor } \\
\text { Strategi Internal }\end{array}$ & Bobot & Rating & Skor & Komentar \\
\hline $\begin{array}{l}\text { Kekuatan } \\
\text { - } \quad \text { Struktur Organisasi yang dimiliki } \\
\text { (TWCB) mencangkup hampir semua } \\
\text { aspek pariwisata berkelanjutan } \\
\text { - Borobudur sudah dikenal secara luas } \\
\text { - } \quad \text { Segment market sangat beragam } \\
\text { - } \quad \text { lklim pariwisata sesuai adat } \\
\text { - } \quad \text { Betimuran } \\
\text { dimiliki } \\
\text { - Fasilitas penunjang pariwisata yang } \\
\text { - } \text { Mengkap } \\
\text { Memiliki tenaga ahli di bidang } \\
\text { - Pelestarian (bkb) } \\
\text { - Program pemberdayaan masyarakat } \\
\text { - Mrogram pemberdyaan budaya } \\
\text { Memiliki studi analisis dampak } \\
\text { lingkungan }\end{array}$ & $\begin{array}{l}0,08 \\
0.07 \\
0.06 \\
0.05 \\
0.05 \\
0.08 \\
0.05 \\
0.04 \\
0.06 \\
0,04 \\
0.07 \\
0,05\end{array}$ & $\begin{array}{l}3 \\
2 \\
3 \\
3 \\
3\end{array}$ & $\begin{array}{l}0,24 \\
0,12 \\
0,28 \\
0,20 \\
0,15 \\
0,08 \\
0,15 \\
0.15 \\
0.12 \\
3.42\end{array}$ & 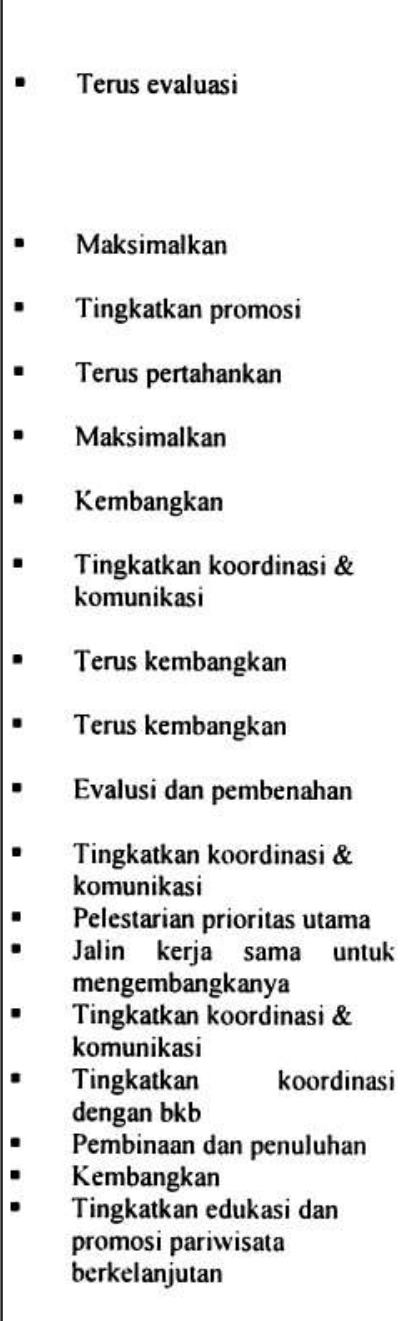 \\
\hline
\end{tabular}

Berdasarkan hasil analisis pada tabel 3, dari 10 peluang dan 8 ancaman yang teridentifikasi, maka total skor dari keseluruhan point tersebut sebesar 3, 42 dimana skor tersebut menunjukan bahwa hasil analisis terhadap faktor internal destinasi wisata candi Borobudur memiliki penilaian yang Sangat Baik.

Selanjutnya adalah penggunaan matrik eksternal-internal untuk mengetahui tingkatan posisi kepariwisataan candi Borobudur dan strategi apa yang tepat untuk dilakukan. Adapun hasil analisis diperoleh dari penempatan total skor faktor eksternal dan internal destinasi wisata Candi Borobudur, maka diketahui posisinya sebagai berikut: 
Tabel 4

Matrik Analisis Eksternal - Internal

Posisi Area Wisata Candi Borobudur

\begin{tabular}{|c|l|l|l|}
\hline & \multicolumn{1}{|c|}{ HIGH (3-4) } & \multicolumn{1}{c|}{ MEDIUM (2-3) } & \multicolumn{1}{c|}{ LOW (1-2) } \\
\hline HIGH (3-4) & $\begin{array}{l}\text { GROWTH } \\
\text { Konsentrasi melalui Integrasi } \\
\text { vertical }\end{array}$ & $\begin{array}{l}\text { GROWTH } \\
\text { Konsentrasi melalui } \\
\text { Intergrasi Horizontal }\end{array}$ & $\begin{array}{l}\text { RETRENCHMENT } \\
\text { Strategi Turn Around }\end{array}$ \\
\hline MEDIUM (2-3) & & $\begin{array}{l}\text { GROWTH } \\
\text { Konsentrasi melalui } \\
\text { integrasi horizontal atau } \\
\text { STABILITY profit strategi }\end{array}$ & $\begin{array}{l}\text { RETRENCHMENT } \\
\text { Strategi Divestasi }\end{array}$ \\
\hline LOW (1-2) & $\begin{array}{l}\text { GROWTH } \\
\text { Diversifikasi Konsentrik }\end{array}$ & $\begin{array}{l}\text { GROWTH } \\
\text { Difersifikasi Konglomerat }\end{array}$ & LIKUIDASI \\
\hline
\end{tabular}

Berdasarkan matriks eksternal-internal pada gambar 1, posisi destinasi wisata candi Borobudur berada pada posisi GROWTH (Tumbuh), sehingga masih sangat berpotensi untuk terus ditingkatkan dan dikembangkan melalui pendekatan Horizontal. Pendekatan Horizontal lebih menekankan pada peminimalan kelemahan untuk memanfaatkan peluang yang akan dihadapi.

\section{Analisis SWOT}

Data hasil analisis SWOT destinasi wisata candi Borobudur:

\section{Kekuatan}

a. Struktur Organisasi yang dimiliki (TWCB) mencangkup hampir semua aspek pariwisata berkelanjutan

b. Borobudur sudah dikenal secara luas

c. Segment market sangat beragam

d. Iklim pariwisata sesuai adat ketimuran

e. Banyak jalinan kerja sama yang dimiliki

f. Fasilitas penunjang pariwisata yang lengkap

g. Memiliki tenaga ahli di bidang pelestarian (bkb)

h. Program pemberdayaan masyarakat

i. Program pemberdyaan budaya

j. Memiliki studi analisis dampak lingkungan

\section{Kelemahan}

a. Stakeholder belum sinergi

b. Kelestarian candi Borobudur sangat rapuh

c. Potensi pariwisata daerah sekitar wisata belum dimaksimalkan

d. Kawasan di sekitar area wisata kurang tertib

e. Manajemen visitor belum berjalan maksimal

f. Pedgang tidak tetib

g. Akomodasi pementasan seni tari tidak maksimal

h. Pengetahuan akan kepariwisata, khususnya pariwisata keberlanjutan masih kurang di antara stake holder. 


\section{Peluang}

a. Agenda wisata sekolah

b. Brand image atau persepsi pengunjung terhadap candi Borobudur tinggi

c. Perhatian pemerintah

d. Perhatian dunia internasional

e. Kunjungan tokoh penting/ negara

f. Adat istiadat/ kebudayaan masyarakat sekitar masih kental

\section{Ancaman}

a. Perilaku pengunjung

b. Bencana alam

c. Kesadaran pengunjung akan pelestarian masih kurang

d. Keberlangsungan aspek ekonomi sangat tergantung pada keberadaan candi Borobudur

e. Perubahan iklim

f. Beban berat pengunjung di atas bangunan candi

Bentuk pengelolaan pariwisata di Candi Borobudur sebagian besar sudah sesuai dengan kaidah-kaidah pariwisata berkelanjutan, pengelolaan pariwisata yang ada sudah mampu memberikan dampak positif terhadap aspek pelestarian destinasi wisata candi Borobudur maupun daerah sekitarnya, seperti adanya program pelestarian budaya, program kebijakan pegawai harus berasal dari masyarakat sekitar, adanya studi analisis terhadap kelestarian candi Borobudur melalui Balai Konservasi Borobudur maupun kelestarian lingkungan sekitarnya. Namun dengan kondisi tersebut masih terdapat beberapa kelemahan, seperti belum bersinerginya stake holder terkait untuk pengembangan destinasi wisata candi Borobudur dan lain sebagainya. Karenanya dibutuhkan pendekatan strategi yang horizontal, yaitu strategi yang meminimalkan kelemahan melalui pemanfaatan peluang yang ada, maka strategi Horizontal yang dapat dilakukan adalah sebagai berikut:

a. Meningkatkan koordinasi dan komunikasi di antara Stakeholder terkait

b. Menggagas skema pemberian edukasi dan informasi pariwisata berkelanjutan yang diakui secara internasional kepada seluruh Stakeholder terkait.

c. Mengajukan konsep pembangunan pasar seni atau cinderamata tersendiri di luar area wisata candi Borobudur, seperti layaknya keberadaan pasar sukowati di Bali, sehingga operasional pedagang di dalam dan sekitar area wisata candi Borobudur dapat dialihkan.

d. Mempromosikan pariwisata daerah sekitar candi Borobudur dan keragaman budayanya kepada wisatawan domestic maupun manca negara

e. Mengajukan konsep pelestarian candi Borobudur secara khusus dan situs arkheologi lainya secara umum agar dapat disisipkan ke dalam kurikulum pembelajaran siswa sekolah.

f. Mengadakan pameran kerajinan, handmade atau hasil industri UKM masyarakat sekitar candi Borobudur dengan tujuan untuk diperkenalkan kepada pengunjung candi Borobudur.

Berdasarkan analisis SWOT pada hasil penelitian, maka diperlukan 4 strategi yang mampu memaksimalkan peluang melalui kekuatan yang dimiliki, meminimalkan kelemahan yang dimiliki melalui peluang yang ada, meminimalkan 
ancaman melalui kekuatan yang dimiliki dan strategi yang mampu meminimalkan kelemahan dan ancaman.

Maka ke empat strategi yang dapat dilakukan adalah sebagai berikut:

\section{Strategi Strenght-Opportunity (S-O)}

a. Menjalinan kerjasama dengan pemerintah dan mitra kerja untuk membentuk konsep pementasan kebudayaan local, konsep pementasan tersebut dapat mengikuti konsep pementasan budaya di Saung Angklung Udjo maupun GWK (Garuda Wisnu Kencana) di Bali, sehingga potensi kebudayaan masyarakat sekitar dapat dimanfaatkan menjadi salah satu komoditi unggulan pariwisata.

b. Membangun komunikasi dan kerjasama dengan banyak sekolah untuk memasukan candi Borobudur ke dalam agenda Study Tour mereka.

c. Menjadikan momen kunjungan tamu penting/negara sebagai bahan promosi area wisata Borobudur kepada dunia internasional.

d. Meningkatkan tarif harga tiket masuk dengan timbal balik penambahan fasilitas bagi pengunjung seperti fasilitas nonton film Borobudur secara gratis, pemberian air mineral secara gratis, pertunjukan kesenian maupun pemberian cinderamata khas Borobudur.

\section{Strategi Weakness-Opportunity (W-O)}

Untuk strategi Weakness - Opportunity dapat digunakan strategi Horizontal pada pembahasan sebelumnya sebagai berikut:

a. Meningkatkan koordinasi dan komunikasi di antara Stakeholder terkait

b. Menggagas skema pemberian edukasi dan informasi pariwisata berkelanjutan yang diakui secara internasional kepada seluruh Stakeholder terkait.

c. Mengajukan konsep pembangunan pasar seni atau cinderamata tersendiri di luar area wisata candi Borobudur, seperti layaknya keberadaan pasar sukowati di Bali, sehingga operasional pedagang di dalam dan sekitar area wisata candi Borobudur dapat dialihkan.

d. Mempromosikan pariwisata daerah sekitar candi Borobudur dan keragaman budayanya kepada wisatawan domestic maupun manca negara

e. Mengajukan konsep pelestarian candi Borobudur secara khusus dan situs arkheologi lainya secara umum agar dapat disisipkan ke dalam kurikulum pembelajaran siswa sekolah.

f. Mengadakan pameran kerajinan, handmade atau hasil industri UKM masyarakat sekitar candi Borobudur dengan tujuan untuk diperkenalkan kepada pengunjung candi Borobudur.

\section{Strategi Strenght-Threat (S-T)}

a. Meningkatkan fokus dan kerja sama diantara pengelola untuk menganalisis perilaku pengunjung, dari mulai masuk ke area wisata, dimulai dari area zona 1, kemudian di zona utama candi Borobudur sampai dengan keluar dari tempat wisata, agar melalui analisis tersebut dapat diketahui factor-faktor apa saja yang dapat menyebabkan perilaku vandalism pengunjung dan bagaimana penangananya.

b. Meningkatkan koordinasi dalam lingkup internal maupun dengan eksternal terkait guna mengantisipasi ancaman datangnya bencana alam maupun perubahan iklim yang dapat berpengaruh negative terhadap kelestarian candi Borobudur. 
c. Dalam setiap kegiatan promosi yang dilakukan, disisipkan juga kontenkonten pelestarian candi Borobudur, sehingga pentingnya kelstarian candi Borobudur dapat diketahui secara luas.

d. Membuat konsep wisata edukasi edukasi, informasi dan pelatihan bagi umum wisatawan maupun masyarakat umum terkait dengan pelestarian dan hal-hal yang bersifat arkeologi

e. Mendorong wisatawan asing maupun lokal agar lebih mengenal kebudayaan, tradisi, kerajinan, tatakrama dan desa wisata di sekitar candi melalui promos ataupun dengan paket wisata yang diintegrasikan dengan tiket candi masuk Borobudur, sehingga ketergantungan ekonomi masyarakat sekitar pada area wisata candi Borobudur dapat dikurangi dan berdampak juga pada pengembangan dan pemanfaatan daerah sekitar area wisata.

f. Membangun media informasi mengenai pelestarian, peraturan dan tata tertib di atas bangunan candi Borobudur kepada pengunjung, dimulai dari memasuki area parkir, loket, area zona 2 dan zona 1. Media informasi yang digunakan dapat berupa papan pengumuman atau papan reklame TV, ataupun pengumuman suara otomatis seperti di perlintasan KA (Kereta Api) dan bentuk media informasi lainya.

\section{Strategi Wekaness-Threat (W-T)}

a. Memberikan fasilitas nonton film Borobudur secara gratis bagi pengunjung di jam ramai kunjungan, sehingga kepadatan pengunjung tidak terkonsentrasi di atas bangunan candi manfaat lainya yang dapat diperoleh adalah pemberian edukasi kepada pengunjung mengenai candi Borobudur dan aspek pelestarinya.

b. Mengadakan pertemuan rutin diantara seluruh Stakeholder terkait untuk membahas hal-hal yang berkaitan dengan areakepariwisataan di candi Borobudur dan sekitarnya, sehingga tingkat koordinasi dan komunikasi diantara Stakeholder dapat terjalin dengan baik.

\section{SIMPULAN}

Berdasarkan hasil penelitian, maka peneliti merumuskan kesimpulan sebagai berikut:

1. Upaya penerapan konsep pariwisata berkelanjutan di destinasi wisata candi Borobudur sudah terlihat, hal tersebut berdasarkan pada beberapa kebijakan yang diberlakukan, dimana beberapa diantaranya sesuai dengan konsep pengelolaan pariwisata berkelanjutan, salah satu kebijakanya yaitu pemberdayaan masyarakat sekitar candi untuk menjadi pegawai.

2. Aspek pelestarian bangunan candi Borobudur sebagai destinasi utama wisata sudah dilakukan secara maksimal, terlihat dari adanya instansi Balai Konservasi Borobudur yang bertugas untuk fokus menjaga kelestarian candi Borobudur.

3. Hambatan utama dalam pelaksanaan program dan kebijakan yang terkait dengan konsep pariwisata berkelanjutan di destinasi wisata candi Borobudur adalah belum bersinerginya stakeholder terkait, sehingga beberapa kebijakan dan program kurang berjalan secara maksimal. 
4. Strategi yang tepat untuk dilakukan oleh pengelola wisata candi Borobudur adalah strategi dengan pendekatan horizontal, yaitu meminimalkan kelemahan dengan peluang yang ada.

Saran yang dapat peneliti sampaikan guna penerapan konsep pariwisata berkelanjutan di destinasi wisata candi Borobudur adalah sebagai berikut:

1. Membentuk SOP (Standard Operasional Prosedur) dan pembuatan kebijakan pengelolaan destinasi wisata candi Borobudur yang disesuaikan dengan konsep pariwisata berkelanjutan.

2. Membangun kerjasama dengan berbagai pihak eksternal guna mensosialisasikan dan mengedukasi masyarakat secara umum mengenai pentinganya pelestarian candi Borobudur guna keberlangsungan aspek kepariwisataanya.

3. Meningkatkan koordinasi dan konsolidasi diantara Stakeholder terkait baik diantara pengelola dan pengelola, diantara pengelola dan masyarakat, diantara pegelola dan pemerintah maupun diantara pengelola dan mitra kerja, sehingga visi yang dicanangkan sebagai world class tourism destination dapat tercapai.

4. Menerapkan strategi Horizontal yang dapat meminimalkan kelemahan dengan peluang yang ada, strategi Horizontal yang dapat dilakukan adalah sebagai berikut :

a. Meningkatkan koordinasi dan komunikasi di antara Stakeholder terkait

b. Menggagas skema pemberian edukasi dan informasi pariwisata berkelanjutan yang diakui secara internasional kepada seluruh Stakeholder terkait.

c. Mengajukan konsep pembangunan pasar seni atau cinderamata tersendiri di luar area wisata candi Borobudur, seperti layaknya keberadaan pasar sukowati di Bali, sehingga operasional pedagang di dalam dan sekitar area wisata candi Borobudur dapat dialihkan.

d. Mempromosikan pariwisata daerah sekitar candi Borobudur dan keragaman budayanya kepada wisatawan domestic maupun manca Negara

e. Mengajukan konsep pelestarian candi Borobudur secara khusus dan situs arkheologi lainya secara umum agar dapat disisipkan ke dalam kurikulum pembelajaran siswa sekolah.

f. Mengadakan pameran kerajinan, handmade atau hasil industri UKM masyarakat sekitar candi Borobudur dengan tujuan untuk diperkenalkan kepada pengunjung candi Borobudur. 


\section{DAFTAR PUSTAKA}

Arsip Balai Konservasi Borobudur

Arsip PT. Taman Wisata Candi Borobudur

Ardana, I Gusti Gde. (1983). Penuntun Ke Obyek-obyek Purbakala Sekitar Desa Pejeng-Bedaulu Gianyar. Denpasar.

Balai Konservasi Borobudur. http://www.konservasiborobudur.org/

Conaghan Aíne, James Hanrahan. I. T. Sligo. Sligo 2010. Demand For And Perceptions Of Sustainable Tourism Certification In Ireland. Fáilte Ireland under the Tourism Research Scholarship Scheme.

Dokumen Pengelolan Lingkungan. 2007. PT Taman Wisata Candi Borobudur.

Harun Rochajat. 2007. Metode Penelitian Kualitatip Untuk Pelatihan. Bandung. Cv. Mandar Maju.

Kusmayadi Dan Sugiarto Endar.2000. Metodologi Penelitian Dalam Bidang Kepariwisataan. Gramedia Pustaka Utama Jakarta.

McKercher, Bob. 2003. Sustainable Tourism Development Guiding Principles For Planning And Management. School of Hotel and Tourism Management, Hong Kong Polytechnic University.

Nabiha Siti, A.K, N. Wahid Abdul, A. Amran, H. Che Haat and I. Abustan. 2008. Jurnal Towards a sustainable tourism management in Malaysia. School of Management, University Sains Malaysia and Malaysia School of Civil Engineerin University Sains Malaysia.

Rangkuti, F. 2006. Analisis SWOT: Teknik Membedah Kasus Bisnis. Penerbit Gramedia Pustaka Utama: Jakarta.

Richard Sharpley, "Tourism and Sustainable Development: Exploring the Theoretical Divice," Journal of Sustainable Tourism, VIII (1), 2000: 1-19.

Widyawati Linda, Nursiyama dan Alie Syahbana, Joesron. 2013. Jurnal Keseriusan Dan Konsekuensi Sikap Pemerintah Daerah Terhadap Pelestarian Di Kawasan Kota Lama Semarang. Fakultas Teknik, Universitas Diponegoro. 